\title{
Astrocyte Precursors in Neonatal Rat Spinal Cord Cultures
}

\author{
Juin Fok-Seang and Robert H. Miller \\ Department of Neurosciences, Case Western Reserve University, School of Medicine, Cleveland, Ohio 44106
}

\begin{abstract}
Cultures of newborn rat spinal cord contain multiple types of astrocytes. By using a combination of cultures enriched for glial precursors and clonal analysis, we have identified a particular astrocyte precursor that gives rise to morphologically distinct classes of astrocytes. This astrocyte precursor labels with the monoclonal antibody A2B5, is highly migratory, proliferates in response to serum and plateletderived growth factor, and differentiates into process-bearing astrocytes, many of which subsequently assume a "pancake"-shaped morphology.

A2B5 + astrocyte precursors share antigenic and migratory characteristics with previously described $02 \mathrm{~A}$ progenitor cells but differ in their response to regulatory factors, including serum and coculture with type 1 astrocytes. More importantly, these astrocyte precursors do not give rise to oligodendrocytes. In their proliferative response to serum and their capacity to differentiate into astrocytes, these glial precursors resemble type 1 astrocyte precursors from optic nerve. However, unlike type 1 astrocyte precursors, these cells are A2B5 +, highly migratory, and do not give rise to fibroblast-like astrocytes.

Neonatal rat spinal cord cultures contain approximately twice the number of the A2B5 + astrocyte precursors than O2A progenitor cells. By contrast, the majority of A2B5+ cells in postnatal day 7 optic nerve cultures are O2A progenitors. The presence of large numbers of A2B5 + astrocyte precursors in rat spinal cord cultures may reflect the more complex cytoarchitecture of the spinal cord compared to the optic nerve.
\end{abstract}

Two major classes of macroglial cells have been identified in the vertebrate CNS: oligodendrocytes and astrocytes (Peters et al., 1976). Oligodendrocytes are responsible for myelin formation (Bunge, 1968) and can be identified in CNS cultures by using antibodies against galactocerebroside (GC) (Raff et al., 1978; Ranscht et al., 1982), the major glycolipid in myelin. Astrocytes can be specifically identified by labeling with antibodies against glial fibrillary acidic protein (GFAP) (Bignami et al., 1972; Bignami and Dahl, 1974), a major component of their intermediate filaments (Schachner et al., 1977).

During development of the vertebrate CNS, the cellular characteristics of glial precursors have been extensively studied in

\footnotetext{
Received Dec. 27, 1991; accepted Feb. 17, 1992.

We thank Drs. A. Hall and S. Landis for helpful comments on the manuscript and E. Noll, C. Maier, H. Zhang, and V. Szigeti for valuable discussion. This work was supported by NIH Grant NS25597. R.H.M. is an Alfred P. Sloan fellow.

Correspondence should be addressed to Robert $\mathrm{H}$. Miller, Department of Neurosciences, Case Western Reserve University, School of Medicine, Cleveland, $\mathrm{OH}$ 44106.

Copyright (C) 1992 Society for Neuroscience $0270-6474 / 92 / 122751-14 \$ 05.00 / 0$
}

a variety of different regions including cortex (Levitt and Rakic, 1980), cerebellum (Schachner, 1982), optic nerve (Skoff et al., 1976a,b), and spinal cord (Gilmore, 1971; Hirano and Goldman, 1988). In the spinal cord, the majority of astrocytes and oligodendrocytes proliferate and differentiate during late embryonic and early postnatal stages of development (Fujita, 1965; Gilmore, 1971; Ling, 1976; Sturrock, 1982), and in general, astrocytes differentiate before oligodendrocytes (Ling, 1976), consistent with similar observations in other regions of the CNS (Skoff et al., 1976a,b). Two distinct hypotheses have been proposed to explain the origin of spinal cord astrocytes and oligodendrocytes. In one, glioblasts initially located in the region of the central canal subsequently migrate to the peripheral white matter, proliferate, and differentiate into astrocytes and oligodendrocytes (Fujita, 1965; Gilmore, 1971). Alternatively, astrocytes and oligodendrocytes may differentiate directly from spinal cord radial glia (Choi et al., 1983; Hirano and Goldman, 1988). The conversion of radial glia into astrocytes has been well documented in other regions of the CNS (Levitt and Rakic, 1980; Culican et al., 1990).

In order to examine the regulation of glial precursor proliferation and differentiation and to address precursor/progeny relationships during glial development, many studies have utilized in vitro analysis (Juurlink et al., 1981; Federoff et al., 1984; Levi et al., 1987; Behar et al., 1988; Raff, 1989; Culican et al., 1990; Miller and Szigeti, 1991). For example, in cortical cultures RC1 (Edwards et al., 1990) immunoreactive radial glial cells subsequently differentiate into astrocytes (Culican et al., 1990). Cultures of neonatal rat optic nerve contain three distinct types of macroglial cells: oligodendrocytes and two types of astrocytes termed type 1 and type 2 astrocytes, which differ in their morphology, antigenic phenotype, and timing of differentiation (Miller et al., 1989; Raff, 1989).

These three types of macroglial cells in optic nerve cultures develop from two distinct precursors. Type 1 astrocytes develop from a precursor that is not highly motile, proliferates in the presence of serum (Abney et al., 1981), and reacts with Ran-2 (Bartlett et al., 1981) but not A2B5 (Eisenbarth et al., 1979) antibodies. By contrast, oligodendrocytes and type 2 astrocytes develop from highly motile (Small et al., 1987), bipotential O2A progenitor cells that label with A2B5 but not Ran-2 antibodies (Raff et al., 1983a,b). The direction of differentiation of O2A progenitor cells depends on environmental cues. In the absence of serum, O2A progenitor cells constitutively differentiate into oligodendrocytes and lose A2B5 expression (Raff et al., 1983a). The development of type 2 astrocytes, however, appears to require the presence of a ciliary neurotrophic factor-like (Barbin et al., 1984) induction factor (Hughes et al., 1988), in combination with an additional extracellular matrix-derived cosignal (Lillien et al., 1990). In the presence of serum, O2A progenitors 
do not proliferate but instead rapidly differentiate into type 2 astrocytes (Raff et al., 1983a). A major mitogen for O2A progenitor cells appears to be platelet-derived growth factor (PDGF) (Noble et al., 1988), which is produced by both type 1 astrocytes (Richardson et al., 1988) and neurons (Sasahara et al., 1991; Yeh et al., 1991). In addition, fibroblast growth factor (FGF) may play an important role in regulating proliferation and differentiation of these progenitor cells (Bogler et al., 1990; McKinnon et al., 1990).

Although cells with antigenic phenotypes corresponding to type 1 astrocyte and $\mathrm{O} 2 \mathrm{~A}$ lineages have been described in cultures of developing cerebellum (Levi et al., 1986a,b) and cerebrum (Behar et al., 1988; Ingraham and McCarthy, 1989), this simple classification may not encompass all astrocytes of the vertebrate CNS. For example, additional types of astrocyte precursors appear to be present in cultures from cerebellum (Schachner, 1982) and mouse neopallium (Federoff and Doering, 1980), while single cell cloning and lineage analyses suggest that cultures from newborn rat spinal cord contain five morphologically distinct classes of astrocytes, some of which do not easily fit into the previous type 1 and type 2 classification (Miller and Szigeti, 1991).

Since the A2B5 antibody distinguishes specific glial precursor cells in cultures from other regions of the CNS, we examined $\mathrm{A} 2 \mathrm{~B} 5+$ cells from newborn rat spinal cord to characterize glial precursors in spinal cord cultures. We show that the A2B5+ glial precursor population in neonatal rat spinal cord cultures comprises two distinct groups of cells that differ in their mitogenic requirements and differentiative capacity. A minor population of $\mathrm{A} 2 \mathrm{~B} 5+$ cells behave like bipotential $\mathrm{O} 2 \mathrm{~A}$ progenitor cells. Most of the A2B5+ cells, however, are astrocyte precursors that give rise to morphologically distinct classes of astrocytes.

\section{Materials and Methods}

Dissociated cell cultures. Dissociated cell cultures were prepared from newborn (P0) cervical and thoracic regions of Sprague-Dawley rat spinal cord as previously described (Warf et al., 1991). Briefly, spinal cords were isolated and the meninges removed. The tissue was finely chopped and incubated at $37^{\circ} \mathrm{C}$ for $30 \mathrm{~min}$ in calcium- and magnesium-free Dulbecco's minimum essential medium (DMEM; GIBCO) containing $0.025 \%$ EDTA (Sigma) and $0.1 \%$ trypsin (Sigma). The trypsin/EDTA mixture was then replaced with an equal volume of $0.05 \mathrm{mg} / \mathrm{ml}$ DNase (Sigma) in DMEM-F12 (GIBCO) and the tissue dissociated by trituration. The cell suspension was passed through Nitex mesh $(30 \mu \mathrm{m}$; Tetko Inc.) and centrifuged for $5 \mathrm{~min}$ at $500 \times \mathrm{g}$. The cells were resuspended in culture medium containing $10 \%$ fetal bovine serum (FBS), counted, and plated onto poly-L-lysine-coated $13-\mathrm{mm}$-diameter glass coverslips at a density of 10,000 viable cells/coverslip. Cultures were grown in DMEM-F12 containing 10\% FBS or in serum-free medium (Bottenstein and Sato, 1979) as required and maintained at $37^{\circ} \mathrm{C}$ in a humidified atmosphere of $5 \% \mathrm{CO}_{2}$. In all cultures, cell viability was determined at the time of plating by trypan blue exclusion.

To remove specific populations of cells by complement-mediated cytolysis, cultures were incubated at $37^{\circ} \mathrm{C}$ for 15 min with A2B5 antibody (1:100 in DMEM-F12) and 1:8 dilution of rabbit complement (GIBCO). The efficiency of cell lysis was determined by comparing the number of A2B + cells surviving the A2B5 antibody and complement treatment with the number of A2B5+ cells in cultures treated with complement alone.

Monolayers of purified type 1 astrocytes were prepared from newborn rat cerebral cortex using standard procedures (Smith et al., 1990). The purity of the monolayers was determined by double immunofluorescent labeling with either A2B5 or anti-GC antibodies in combination with anti-GFAP staining. Only sister cultures of astrocyte monolayers containing no detectable $\mathrm{A} 2 \mathrm{~B} 5$ - or $\mathrm{GC}$-immunoreactive cells were used in subsequent experiments.
Optic nerve cultures were prepared from 7-d-old (P7) rats as previously described (Miller et al., 1985) and plated at a density of 10,000 viable cells/coverslip. Conditioned medium was prepared from optic nerve and spinal cord cultures following a 3-4 d incubation in serumfree medium. Conditioned medium was diluted $1: 1$ with fresh medium before use.

Explant cultures. Explant cultures of $\mathrm{PO}$ spinal cord were prepared from cervical and thoracic segments by chopping the tissue into small pieces and forcing the pieces through a $500 \mu \mathrm{m}$ Nitex filter twice. The tissue pieces were then resuspended and plated in DMEM-F12 containing $10 \%$ FBS on poly-L-lysine-coated $13 \mathrm{~mm}$ coverslips at a density of 10-20 explants/coverslip.

To obtain cultures enriched for migratory process-bearing cells, explants were grown for $2 \mathrm{~d}$ to allow emigration of process-bearing cells and then the bulk of the explant containing nonmigratory cells was detached from the substrate by a jet of culture medium from a Pasteur pipette. Although the resultant cultures were greatly enriched for process-bearing cells $(70-80 \%$ compared to $40-45 \%)$, a significant number of flat type 1-like astrocytes also remained. In some experiments, clonal cultures were prepared (Miller and Szigeti, 1991). In such cases, P0 spinal cord explants were grown for $1-2 \mathrm{~d}$ in a poly-L-lysine-coated 25 $\mathrm{cm}^{2}$ tissue culture flask and then dislodged by shaking. The migratory cells remaining were detached after a further day in culture by incubating them at $37^{\circ} \mathrm{C}$ for $15 \mathrm{~min}$ with trypsin/EDTA. The cells were replated at a density of 50 cells/coverslip on a poly-L-lysine substrate or on a monolayer of rat cortical type 1 astrocytes.

Antibodies and immunofluorescent staining. To identify particular cell types in both dissociated and explant cultures, cells were labeled by indirect immunofluorescence using specific antibody reagents. These antibodies included A2B5 (Eisenbarth et al., 1979) to label O2A progenitor cells and type 2 astrocytes (Raff et al., 1984; ascites fluid, 1: 100), anti-galactocerebroside (Ranscht et al., 1982) to identify oligodendrocytes (ascites fluid, 1:200), O4 (Sommer and Schachner, 1981) to identify $\mathrm{O} 2 \mathrm{~A}$ progenitor cells and immature oligodendrocytes (hybridoma supernatant, 1:5), monoclonal anti-vimentin to identify immature glial precursors (1:50; Oncogene Science), rabbit anti-GFAP antiserum to identify astrocytes (1:100; Axell), and anti-neurofilament (1:50; Sigma) to identify neurons. To visualize cell surface antigens, such as those recognized by $\mathrm{A} 2 \mathrm{~B} 5, \mathrm{O} 4$, and anti-GC antibodies, cells were labeled prior to fixation, while intracellular antigens such as vimentin and GFAP were detected following 10 min fixation with 5\% acetic acid in methanol at $-20^{\circ} \mathrm{C}$. All antibodies were diluted in DMEM containing 10\% normal goat scrum (NGS), and incubations were for 30 min at room temperature. Binding of primary antibodies was detected using rhodamine-conjugated goat anti-mouse IgG (Cappel) for mouse antibodies and fluorescein-conjugated sheep anti-rabbit IgG (Cappel) for rabbit antibodies. When immunoglobulin class-specific reagents were required, for example, in double-label experiments with $\mathrm{A} 2 \mathrm{~B} 5$ and anti$\mathrm{GC}$ antibodies, rhodamine-conjugated goat anti-mouse IgM (FisherBiotech) and fluorescein-conjugated goat anti-mouse IgG3, respectively (FisherBiotech), were used. All secondary antibodies were used at a concentration of 1:100 in DMEM containing 10\% NGS. Specificity of immunoreactivity was confirmed in control experiments either by labeling with secondary antibody alone or in combination with an appropriate normal serum substituted for the first antibody.

BrdU incorporation assay. To determine the extent of cell proliferation under different experimental conditions, a bromodeoxyuridinc (BrdU) incorporation assay was used (Nowakowski et al., 1989). BrdU is a thymidine analog that is incorporated into the DNA of proliferating cells during S-phase. Cells that have undergone division in the presence of BrdU can then be specifically identified by indirect immunofluorescence using anti-BrdU antibodies (Yong and Kim, 1987).

To assess the influence of serum and other growth factors on spinal cord glial precursor proliferation, complete or A2B5+ cell-enriched spinal cord cultures were grown for $18 \mathrm{hr}$ in serum-free medium to allow proliferation to reach basal levels. The medium was then replaced with one containing growth factors at the following concentrations: $10 \%$ FBS, $2 \mathrm{ng} / \mathrm{ml}$ FGF (Collaborative Research Inc.), or $6 \mathrm{ng} / \mathrm{ml}$ PDGF (Collaborative Research Inc.). Cells were grown for $2 \mathrm{~d}$ in the presence of growth factors, and for the last $18 \mathrm{hr}$ of that period, $20 \mu \mathrm{M}$ BrdU (Sigma) was added to the culture medium. A2B5 + cells that had actively prolifcratcd during the final $18 \mathrm{hr}$ in the presence of growth factor were then identified by double-labeling indirect immunofluorescence analysis using A2B5 and mouse anti-BrdU antibodies. The method used for this double label was similar to that described above, with the exception that cells were 
Table 1. Effects of serum on glial cell differentiation in cultures from P7 optic nerve or P0 spinal cord

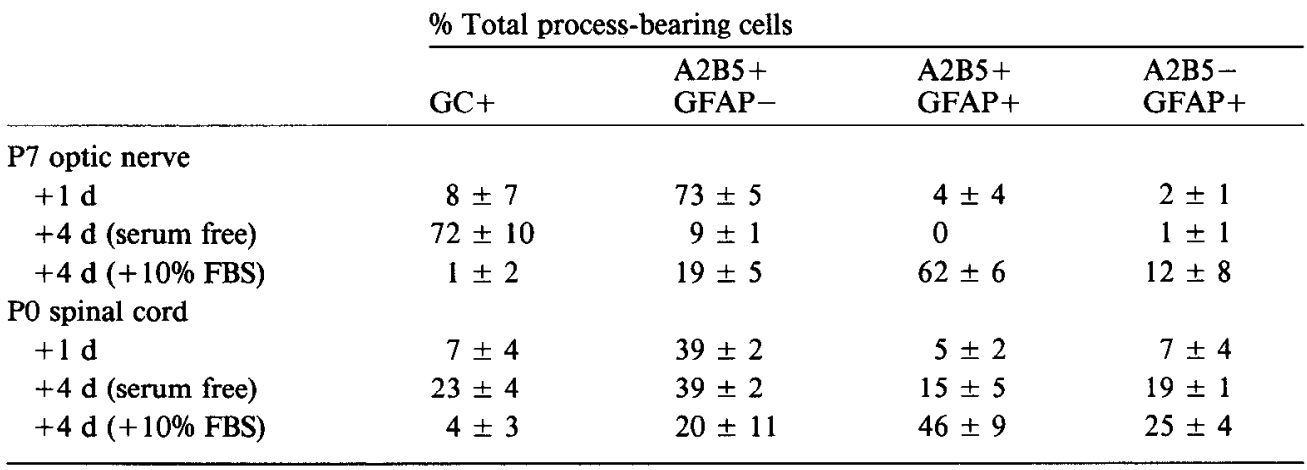

The differentiation of process-bearing cells in optic nerve and spinal cord cultures was qualitatively similar, but quantitatively different. Dissociated cells from P7 optic nerve and P0 spinal cords were grown in the absence or presence of serum for 1 and $4 \mathrm{~d}$, and the proportion of process-bearing cells expressing A2B5, GC, and GFAP was determined. In optic nerve cultures, the majority of process-bearing cells were A2B5+ and most of these differentiated into GC+ oligodendrocytes after $4 \mathrm{~d}$ in the absence of serum, or into GFAP+ astrocytes in the presence of serum. By contrast, in spinal cord cultures, a significantly smaller proportion of process-bearing cells labeled with A2B5 than in optic nerve cultures, and although more oligodendrocytes developed in the absence than in the presence of serum, the differentiation of A2B5 + cells into oligodendrocytes was less complete in spinal cord cultures than in optic nerve. Furthermore, in spinal cord, but not optic nerve cultures, a significant number of A2B5+ cells and GFAP+ astrocytes developed in the absence of serum. In spinal cord cultures, the remaining process-bearing cells probably represent a combination of $\mathrm{O} 4+$ oligodendrocytes and A2B5 - glial precursors. The data represent the mean \pm SD from at least three separate experiments.

treated for 10 min with $2 N \mathrm{HCl}$ immediately after fixation to render the DNA accessible to the anti-BrdU antibody (1:20; Boehringer Mannheim). In all cases, coverslips were mounted in glycerol containing $5 \%$ $n$-propyl gallate to prevent fluorescence fading, and labeled cells were examined with a Nikon Optiphot fluorescence microscope equipped with appropriate rhodamine and fluorescein filters and photographed on Tri-X film (ASA 400).

Quantitation of glial cell populations. To determine the relative numbers of distinct cell types that developed under different culture conditions, cells were labeled with cell-type-specific antibodies and examined as above. Process-bearing cells were defined as cells with a small, round cell body and at least two processes each of which was more than a cell body diameter in length. In all cases, the total number of cells of a particular morphology and antigenic phenotype was determined and expressed as a percentage of total cell number. More than 200 cells were counted from duplicate coverslips in each experiment, and experiments were repeated a minimum of three times.

\section{Results}

Developing rat spinal cord cultures contain multiple types of glial cells

To assess the extent of glial cell diversity in P0 rat spinal cord, low-density dissociated cell cultures were grown for $1-4 \mathrm{~d}$ under different conditions and stained with cell-type-specific antibodies. Cultures grown in the absence of serum contained processbearing cells, which consisted of cells with an antigenic phenotype characteristic of $\mathrm{O} 2 \mathrm{~A}$ progenitors (A2B5+, $\mathrm{GC}-$, GFAP-), GC-immunoreactive oligodendrocytes (Fig. $1 a-c$ ), and both $\mathrm{A} 2 \mathrm{~B} 5+, \mathrm{GFAP}+$ and $\mathrm{A} 2 \mathrm{~B} 5-$, GFAP+ astrocytes. In addition, flat A2B5-, GFAP+ astrocytes were also present in these cultures. In the presence of serum, spinal cord cultures contained many more process-bearing and flat astrocytes and most of the process-bearing astrocytes were A2B5 immunoreactive (Fig. $1 d-f$ ). Furthermore, far fewer GC+ oligodendrocytes were found in cultures grown in the presence of serum. In cultures grown for $4 \mathrm{~d}$ in either the presence or absence of serum, less than $1 \%$ of the cells were neurofilament-immunoreactive neurons, presumably because neurons failed to survive in the low-density culture conditions.

To determine if those cells in spinal cord cultures with an antigenic phenotype similar to optic nerve $\mathrm{O} 2 \mathrm{~A}$ progenitor cells (i.e., $\mathrm{A} 2 \mathrm{~B} 5+, \mathrm{GC}-$, $\mathrm{GFAP}$-) also gave rise to oligodendrocytes or $\mathrm{A} 2 \mathrm{~B} 5+$ astrocytes, two different approaches were taken. First, A2B5 + cells were selectively eliminated from newborn rat spinal cord cultures by treatment with A2B5 antibody and rabbit complement. Cultures were then grown for $4 \mathrm{~d}$ in the presence or absence of serum and the antigenic phenotype of the surviving cells determined by indirect immunofluorescence. No oligodendrocytes or A2B5-immunoreactive astrocytes were seen in either culture condition after such treatment, even though large numbers of flat and process-bearing A2B5- astrocytes developed. This observation indicates that the subsequent development of oligodendrocytes and A2B5 + astrocytes in spinal cord cultures is dependent on the continued presence of A2B5+ cells. Second, previous studies in P7 optic nerve cultures have demonstrated the almost total conversion of A2B5+ cells to either oligodendrocytes or type 2 astrocytes depending on the culture environment (Raff et al., 1983a). Since GC+ oligodendrocytes appear almost a week earlier in spinal cord than in optic nerve (Warf et al., 1991), the differentiation of A2B5+ cells from P0 spinal cord cells was compared to that of A2B5+ cells from P7 optic nerve in the absence and presence of serum. In both spinal cord and optic nerve cultures, more oligodendrocytes developed in the absence of serum than in the presence of serum (Table 1). In addition, in both cultures fewer A2B5+ astrocytes developed in the absence of serum than in its presence (Table 1). These results suggest that spinal cord, like optic nerve cultures, contain a population of A2B5 + bipotential progenitor cells whose differentiative pathway is influenced by the presence of serum in the medium.

Although optic nerve and spinal cord cultures were similar in their general response to environmental manipulations, quantitative analyses of glial development revealed several important differences between cultures derived from the two regions. First, in optic nerve cultures, more than $70 \%$ of the process-bearing cells were oligodendrocytes after $4 \mathrm{~d}$ in the absence of serum, while in spinal cord cultures grown under similar conditions, 

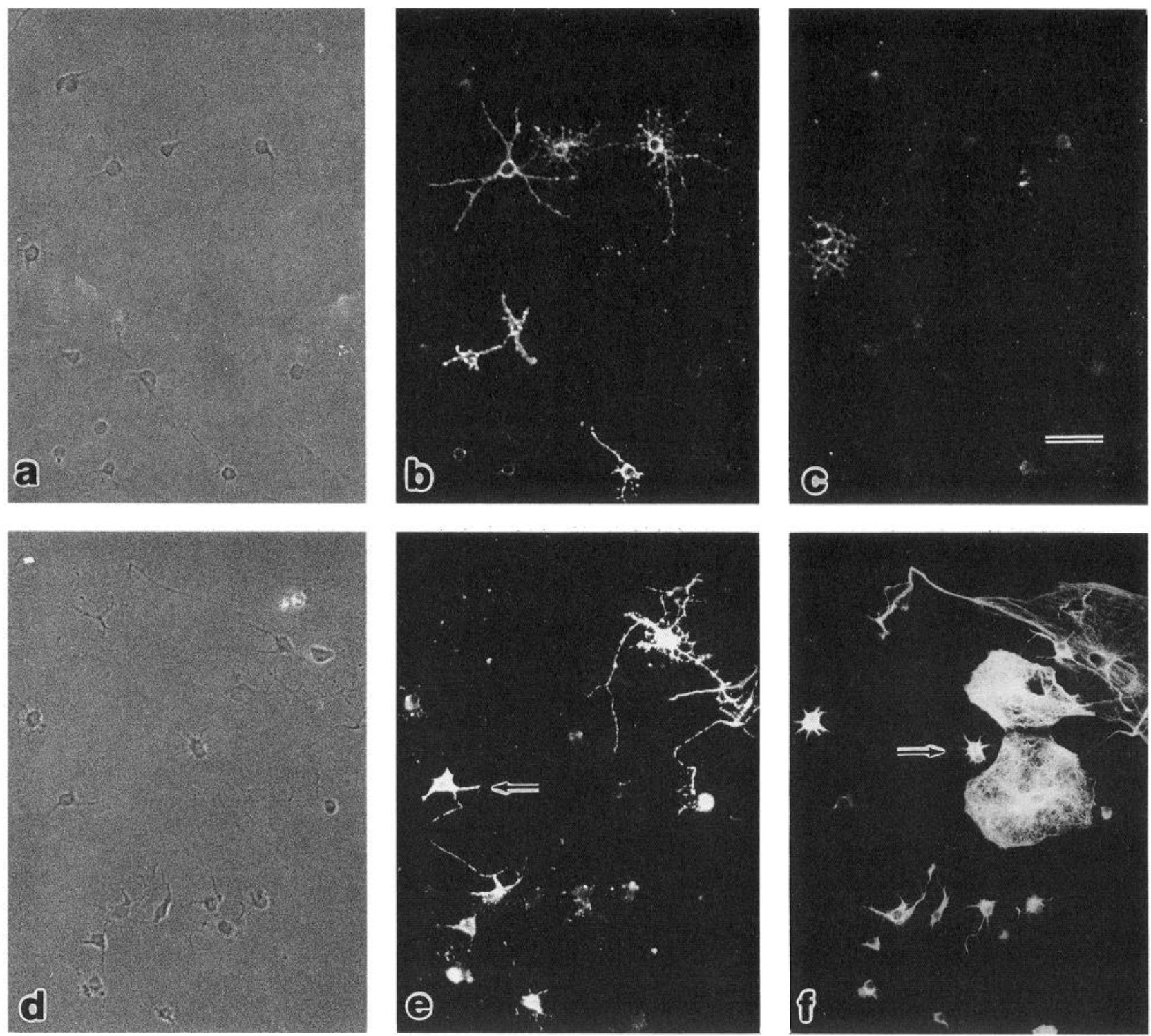

Figure 1. P0 rat spinal cord cells grown for $4 \mathrm{~d}$ in the absence $(a-c)$ or presence $(d-f)$ of $10 \%$ FBS. Cells were labeled with A2B5 antibody $(b$ and $e)$ and either anti-GC $(c)$ or anti-GFAP antibodies $(f)$. In the absence of serum many process-bearing cells are A2B5+, GC-, although some GC + oligodendrocytes are also seen $(c)$. By contrast, in the presence of serum, many of the A2B5+ process-bearing cells are also GFAP+, although both $\mathrm{A} 2 \mathrm{~B} 5+, \mathrm{GFAP}-($ arrow in $e$ ) and A2B5-, GFAP+ $($ arrow in $f$ ) process-bearing cells were seen. Flat A2B5- astrocytes are also present. $a$ and $d$, phase-contrast images. Scale bar, $50 \mu \mathrm{m}$.

only $23 \%$ were oligodendrocytes (Table 1 ). Second, in optic nerve cultures, the appearance of oligodendrocytes was accompanied by a corresponding depletion of A2B $5+$ progenitor cells, while in spinal cord cultures the proportion of A2B5+ progenitor cells remained relatively constant, suggesting either proliferation of A2B5 + cells or recruitment from an A2B5- population. Finally, while more than $70 \%$ of the process-bearing cells in both optic nerve and spinal cord cultures were GFAP+ after $4 \mathrm{~d}$ in the presence of serum, in optic nerve cultures virtually all process-bearing astrocytes were A2B + , while about $25 \%$ were A2B5 - in spinal cord cultures. Thus, in spinal cord cultures, the presence of significant numbers of A2B5- processbearing cells in the starting population, combined with the development of numerous process-bearing astrocytes in serumfree cultures, suggests that spinal cord cultures contain additional astrocyte types not present in optic nerve cultures. It is likely that the additional astrocyte types in spinal cord cultures are derived from distinct astrocyte precursors.

\section{$A 2 B 5+$ glial precursor cells selectively migrate from spinal cord explants}

In optic nerve cultures, A2B5+ glial precursors are known to be highly motile (Temple and Raff, 1985; Small et al., 1987; Noble et al., 1988). We took advantage of the migratory capacity of A2B5 + glial precursors to obtain cultures from neonatal rat spinal cord enriched for these cells. Process-bearing cells migrated away from P0 rat spinal cord explants in 1-2 d, after which the explants were removed and the properties of the remaining cells characterized. Approximately $200-500$ cells remained on each coverslip after explant removal, $70-80 \%$ of which were A2B5 + and had a process-bearing morphology while less than $20 \%$ were flat fibroblastic cells, indicating a substantial 

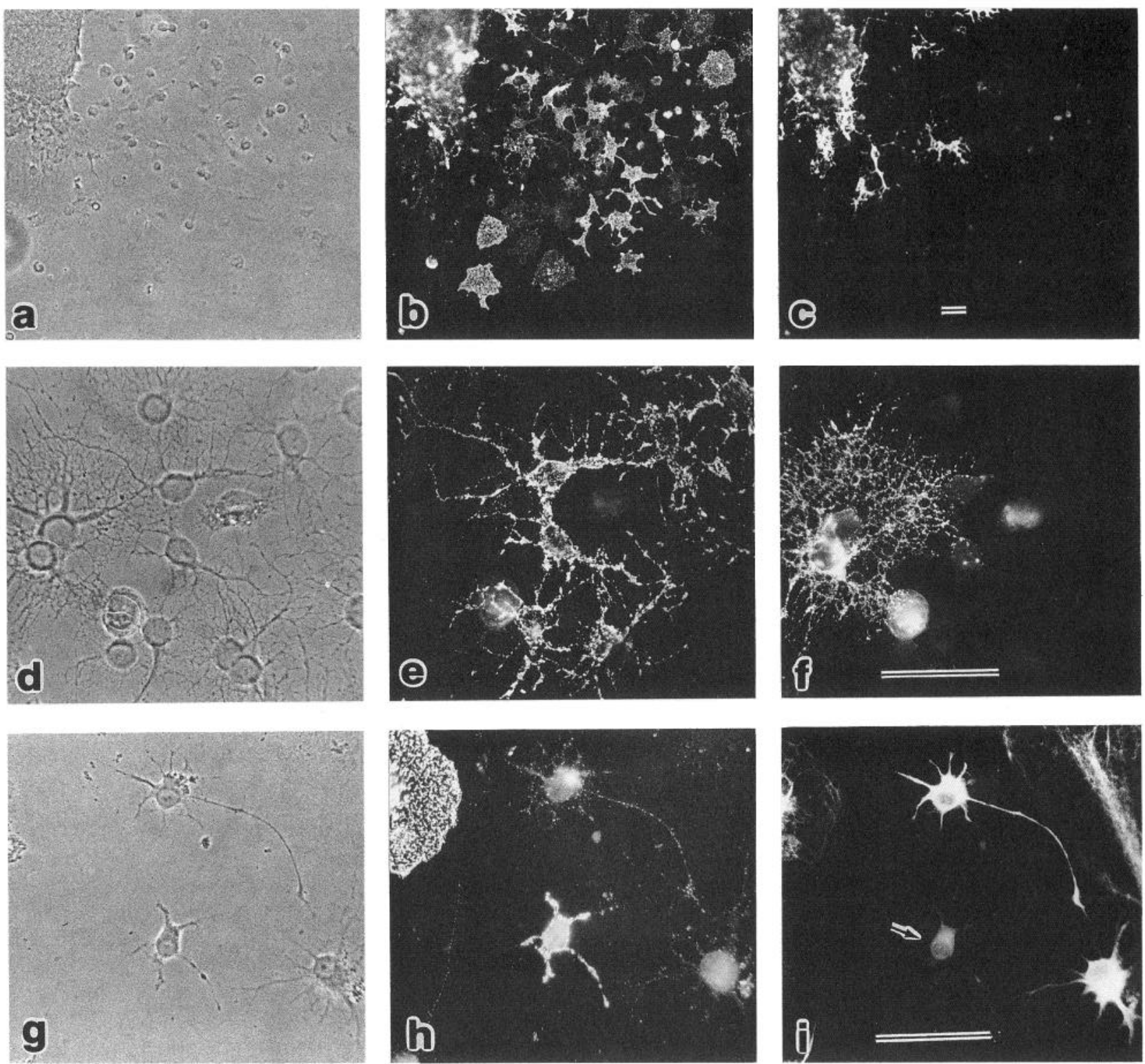

Figure 2. $a-c$, A P0 spinal cord explant cultured for $2 \mathrm{~d}$ in the absence of serum and labeled with A2B5 (b) and anti-GC antibodies (c). Many of the cells that have migrated from the explant are A2B5 + , and a small proportion of those are also GC + oligodendrocytes. $d-f$, Process-bearing migratory cells $2 \mathrm{~d}$ after explant removal (4 d total culture in the absence of serum) labeled with A2B5 (e) and anti-GC antibodies $(f)$. $g-i$, Processbearing cells $2 \mathrm{~d}$ after explant removal, grown for $2 \mathrm{~d}$ in absence of serum, followed by $2 \mathrm{~d}$ in presence of serum, labeled with A2B5 $(h)$ and antiGFAP antibodies (i). Most of the process-bearing cells remain A2B5+. Many of these cells are now GFAP+, and only a few A2B5+, GFAPcells are seen (arrow in $i$ ). Some cells have also assumed a less process-bearing morphology. $a, d$, and $g$, phase-contrast images. Scale bars: $c$, 50 $\mu \mathrm{m}($ for $a-c) ; f, 50 \mu \mathrm{m}$ (for $d-f), i, 50 \mu \mathrm{m}$ (for $g-i)$.

enrichment for A2B5+ process-bearing cells (Fig. 2). These A2B5 + cells exhibited many characteristics of glial precursors. More than $90 \%$ labeled with anti-vimentin antibodies (data not shown), a characteristic of immature glial cells, while less than $5 \%$ expressed detectable levels of either the oligodendrocyte maker GC, or the astrocyte marker GFAP. Further, approximately $15 \%$ of process-bearing cells labeled with the monoclonal antibody $\mathrm{O} 4$, an antigenic characteristic shared by $\mathrm{O} 2 \mathrm{~A}$ progenitor cells and immature oligodendrocytes (Schachner et al., 1981; Sommer and Schachner, 1981). The significant enrichment of A2B5 + spinal cord glial precursors provided by this procedure allowed further analysis of their differentiative capacity.

\section{A2B5 + cells give rise to astrocytes and oligodendrocytes}

To determine whether the A2B5+ cell-enriched cultures have the capacity to give rise to oligodendrocytes and astrocytes, cells were grown for $4 \mathrm{~d}$ in the presence or absence of serum. In the presence of serum, more than $75 \%$ of the process-bearing cells were astrocytes (Table 2) and the majority of these cells were A2B5 immunoreactive (Fig. 2). In the absence of serum, however, only $17 \%$ of the process-bearing cells differentiated into GC+ oligodendrocytes (Fig. 2), while 25\% differentiated into astrocytes most of which were A2B5+ (Table 2). A significant proportion (approximately 61\%) of the remaining A2B5+ cells retained an undifferentiated progenitor-like phenotype. The low 
Table 2. Effects of serum on the differentiation of A2B5 + cell-enriched P0 spinal cord cultures

\begin{tabular}{lcccc}
\multicolumn{5}{c}{ \% Total process-bearing cells } \\
\cline { 2 - 5 } & GC+ & A2B5+ & A2B5+ & A2B5- \\
& $4 \pm 2$ & GFAP- & GFAP+ & GFAP+ \\
\hline$+1 \mathrm{~d}$ & $17 \pm 10$ & $63 \pm 7$ & $3 \pm 3$ & $1 \pm 1$ \\
$+4 \mathrm{~d}$ (serum free) & $1 \pm 2$ & $5 \pm 5$ & $23 \pm 12$ & $2 \pm 2$ \\
$+4 \mathrm{~d}(+10 \%$ FBS) & $77 \pm 21$ & $1 \pm 3$ \\
\hline
\end{tabular}

Cultures of $\mathrm{P} 0$ rat spinal cord enriched for $\mathrm{A} 2 \mathrm{~B} 5+$ cells gave rise to both oligodendrocytes and astrocytes when grown in the absence of serum, but only to astrocytes when grown in the presence of serum. In the absence of serum, only $17 \%$ of process-bearing cells from A2B5 + cell-enriched cultures differentiated into oligodendrocytes after $4 \mathrm{~d}$, while an equal number of A2B5 + cells differentiated into astrocytes. Most A2B5 + process-bearing cells in these cultures retained a progenitor-like phenotype. Even when cultures were maintained for a further $12 \mathrm{~d}$, the number of oligodendrocytes did not increase beyond $35 \%$ of process-bearing cells, suggesting that only $35 \%$ of the A2B + cells have that capacity to differentiate into oligodendrocytes. In sister cultures grown in the presence of serum, the vast majority of A2B5+ cells differentiated into GFAP+ astrocytes within $4 \mathrm{~d}$. The number of cells of a particular antigenic phenotype is expressed as the proportion of the total number of process-bearing cells examined. The data represent the mean \pm SD of at least three separate experiments.

number of oligodendrocytes in these serum-free cultures appeared to result from a lack of oligodendrocyte differentiation rather than a lack of oligodendrocyte precursor survival. For example, in a typical experiment, quantitation of A2B5-immunoreactive cells demonstrated $208 \pm 68$ cells/coverslip after $1 \mathrm{~d}, 253 \pm 22$ after $4 \mathrm{~d}$ in the abscnce of scrum, and $315 \pm 19$ after $4 \mathrm{~d}$ in the presence of serum, suggesting that the actual number of $\mathrm{A} 2 \mathrm{~B} 5+$ cells did not change significantly during the experiment. Furthermore, the small proportion of $\mathrm{GC}+$ oligodendrocytes that developed in these cultures was not simply a reflection of delayed differentiation, since even when spinal cord cultures were maintained for a further $12 \mathrm{~d}$, the proportion of GC+ oligodendrocytes never increased beyond 35\% (data not shown). These findings contrast sharply with results from studies on the optic nerve, where under similar conditions, more

Table 3. Effects of conditioned media on P0 and P7 spinal cord and P7 optic nerve cultures

$\%$ Total process-bearing cells

GC+ A2B5+

\begin{tabular}{|c|c|c|c|}
\hline \multirow[t]{4}{*}{ A. } & \multicolumn{3}{|l|}{ P7 optic nerve cultures } \\
\hline & Serum free & $71 \pm 9$ & $38 \pm 5$ \\
\hline & $+\mathrm{P} 0$ spinal cord $\mathrm{CM}$ & $71 \pm 11$ & $53 \pm 9$ \\
\hline & +P7 spinal cord $\mathrm{CM}$ & $64 \pm 14$ & $57 \pm 10$ \\
\hline \multirow[t]{3}{*}{ B. } & P0 spinal cord cultures & & \\
\hline & Serum free & $11 \pm 5$ & $90 \pm 8$ \\
\hline & +P7 optic nerve CM & $16 \pm 7$ & $84 \pm 8$ \\
\hline \multirow[t]{4}{*}{ C. } & P7 spinal cord cultures & & \\
\hline & Serum free & $27 \pm 7$ & $80 \pm 7$ \\
\hline & +P7 optic nerve CM & $31 \pm 11$ & $74 \pm 6$ \\
\hline & $+\mathrm{P} 0$ spinal cord $\mathrm{CM}$ & $25 \pm 5$ & $80 \pm 5$ \\
\hline
\end{tabular}

The differentiation of optic nerve and spinal cord glial precursors into oligodendrocytes is unaffected by growing the cells in inappropriate conditioned media (CM). P7 optic nerve and P0 and P7 spinal cord cells were grown for $4 \mathrm{~d}$ in serumfree media or conditioned media from inappropriate cultures, and the proportion of A2B5+ cells and oligodendrocytes in the culture was determined. In optic nerve cultures, approximately $70 \%$ of the process-bearing cells were $\mathrm{GC}+$ oligodendrocytes after $4 \mathrm{~d}$ in culture regardless of the conditioned medium in which the cells were grown. By contrast, in P0 spinal cord cultures approximately $15 \%$ of the process-bearing cells were GC+ oligodendrocytes even when the cells were grown in optic nerve-conditioned medium. In P7 spinal cord cultures, approximately $30 \%$ of the process-bcaring cells differentiated into oligodendrocytes under al conditions tested. In all cases, spinal cord cultures were A2B5+ cell enriched. Data represent mean \pm SD taken from at least three separate experiments. than $70 \%$ of $\mathrm{A} 2 \mathrm{~B} 5+$ process-bearing cells differentiated into oligodendrocytes in the absence of serum (compare Tables 1 and 2).

The different responses of spinal cord and optic nerve glial precursors in the presence and absence of serum may reflect cither differences in the cellular and molecular environment of the two culture systems, or the presence of intrinsically different cell types in the two cultures. To examine the influence of environmental factors on the differentiation of oligodendrocytes, $\mathrm{A} 2 \mathrm{~B} 5+$ cell-enriched cultures from $\mathrm{P} 0$ and $\mathrm{P} 7$ spinal cord were grown in the presence of $\mathrm{P} 7$ optic nerve-conditioned media, while P7 optic nerve cells were grown in the presence of $\mathrm{P} 0$ and P7 spinal cord-conditioned media. The proportion of GC + cells under each condition was determined after $4 \mathrm{~d}$ in culture (Table 3 ). In no case did the addition of conditioned medium significantly alter the proportion of oligodendrocytes that developed in each culture (Table 3 ), although in all cases cell survival was enhanced.

While it remains possible that some cell-cell interaction is altering the response of $\mathrm{A} 2 \mathrm{~B} 5+$ glial precursors in spinal cord cultures, the most likely interpretation of these observations is that intrinsic ccllular diffcrences rather than environmental influences are predominantly responsible for the difference in response of spinal cord and optic nerve glial precursors. Thus, we propose that in spinal cord cultures, although both processbearing astrocytes and oligodendrocytes develop from A2B5+ cells, these cultures contain two separate populations of $\mathrm{A} 2 \mathrm{~B} 5+$ glial precursors. One precursor has similar characteristics to $\mathrm{O} 2 \mathrm{~A}$ progenitor cells, while the other population of $\mathrm{A} 2 \mathrm{~B} 5+$ glial precursors does not differentiate into oligodendrocytes in the absence of serum, but instead either retains a precursor-like phenotype, or differentiates into $\mathrm{A} 2 \mathrm{~B} 5+$ process-bearing astrocytes. These cells will be referred to as A2B5+ astrocyte precursors to distinguish them from bipotential $\mathrm{O} 2 \mathrm{~A}$ progenitor cells.

\section{Two distinct $A 2 B 5+$ glial precursors in newborn rat spinal cord cultures}

To examine the developmental potential of individual glial precursors from rat spinal cord, A2B5+ cell-enriched cultures were grown on a poly-L-lysine substrate at clonal density in the absence or presence of serum. After $4 \mathrm{~d}$ in vitro, the antigenic phenotype of the clonal progeny was assayed by indirect im- 
Table 4. Clonal analysis of A2B5 + glial precursors from P0 rat spinal cord

Proportion of clones containing specified cell type

Cell type composition of clone

Serum free $10 \%$ FBS

A. On poly-L-lysine substrate

Glial precursors alone (A2B5+, GC-, GFAP-)

$\sim 50 \%$

$14 \%(5 / 37)$

Oligodendrocytes alone $(\mathrm{GC}+)$

Astrocytes alone (GFAP + )

Glial progenitors and oligodendrocytes

Glial precursors and astrocytes

B. On cortical type 1 astrocyte monolayer

Glial precursors alone (A2B5+, GC-, GFAP-)

Oligodendrocytes alone $(\mathrm{GC}+)$

Astrocytes alone (GFAP+)

Glial progenitors and oligodendrocytes

Glial precursors and astrocytes
$8 \%(3 / 32)$

$24 \%(9 / 37)$

$6 \%(2 / 32)$

$\begin{array}{cc}0 \% & \sim 25 \% \\ 7 \%(3 / 41) & 0 \%(0 / 21) \\ 3 \%(1 / 36) & 17 \%(3 / 18) \\ 27 \%(11 / 41) & 0 \%(0 / 21) \\ 75 \%(27 / 36) & 67 \%(12 / 18)\end{array}$

$\sim 7 \%$

$0 \%(0 / 43)$

$0 \%(0 / 42)$

$5 \%(2 / 43)$

$79 \%(33 / 42)$

$67 \%(12 / 18)$

A2B5+ cell-enriched cultures were grown in the absence or presence of serum at clonal density either on a poly-L-lysine substrate for $4 \mathrm{~d}(\mathrm{~A})$ or on a monolayer of type 1 astrocytes for $6 \mathrm{~d}(\mathrm{~B})$, and the antigenic phenotype of the clonal progeny was determined. On a poly-L-lysine substrate, more clones contained some GC+ oligodendrocytes in the absence of serum than in the presence of serum. By contrast, more clones contained some astrocytes in the presence of serum than in the absence of serum. In large part, this appeared to reflect the differentiation of A2B5+ astrocyte precursors into astrocytes in the presence of serum. On an astrocyte monolayer, in the absence of serum, the same number of clones contained oligodendrocytes. However, the number of clones containing astrocytes increased dramatically over that seen on a poly-L-lysine substrate while the number of undifferentiated progenitor clones decreased, suggesting that coculture with type 1 astrocytes had no effect on $\mathrm{O} 2 \mathrm{~A}$ progenitor cell differentiation, but induced astrocyte differentiation in $\mathrm{A} 2 \mathrm{~B} 5+$ astrocyte precursors. In the presence of serum, no oligodendrocyte-containing clones developed and the number of astrocyte-containing clones increased from that seen in the absence of serum. This increase most likely reflects the differentiation of $\mathrm{O} 2 \mathrm{~A}$ progenitors into type 2 astrocytes in the presence of serum. The data represent percentages of clones with progeny of a particular phenotype. The actual numbers of clones assayed are shown in parentheses. The number of exclusively precursor clones is calculated from the number of $\mathrm{A} 2 \mathrm{~B} 5+$ clones minus the number of $\mathrm{GC}+$ or GFAP+ cell-containing clones.

munofluorescence with A2B5, anti-GC, and anti-GFAP antibodies. In the absence of serum, $38 \%$ of clones contained $\mathrm{GC}+$ oligodendrocytes (Table $4 A$ ), and more than half of these clones also contained A2B5+ O2A progenitor cells (Fig. 3). Fifteen percent of clones contained GFAP + astrocytes, approximately half of which also included A2B5 + precursor cells, suggesting that some precursors constitutively gave rise to astrocytes. Approximately $50 \%$ of clones, however, comprised exclusively A2B5+ precursor cells, suggesting that these glial precursors required a signal to undergo differentiation (Table $4 A$ ). By contrast, in the presence of serum, only $5 \%$ of clones contained any oligodendrocytes, while more than $75 \%$ contained astrocytes (Fig. 3). Furthermore, the number of clones comprised exclusively of A2B + precursors was substantially smaller than that seen in the absence of serum (Table $4 A$ ). These observations suggest that in the absence of serum, A2B5 + O2A progenitor cells differentiated into oligodendrocytes, while the A2B $5+$ astrocyte precursors either retained a precursor phenotype, or differentiated into A2B5+ astrocytes. In the presence of serum, however, both $\mathrm{O} 2 \mathrm{~A}$ progenitor cells and the A2B + astrocyte precursors differentiated into astrocytes.

Although serum induced astrocyte differentiation in both $\mathrm{O} 2 \mathrm{~A}$ progenitor and $\mathrm{A} 2 \mathrm{~B} 5+$ astrocyte precursor populations, the regulation of differentiation appeared to be different. For example, when optic nerve O2A progenitor cells were grown on a type 1 astrocyte monolayer in the absence of serum, they differentiated into oligodendrocytes as they did on poly-L-lysine. Spinal cord $\mathrm{O} 2 \mathrm{~A}$ progenitors appeared to behave in a similar manner. When A2B 5 + spinal cord cells, which contained both $\mathrm{O} 2 \mathrm{~A}$ progenitors and $\mathrm{A} 2 \mathrm{~B} 5+$ astrocyte precursors, were grown at clonal density on astrocyte monolayers for $6 \mathrm{~d}$ in the absence of serum, the proportion of clones containing oligodendrocytes was similar to that seen on poly-L-lysine, suggesting that differentiation of spinal cord $\mathrm{O} 2 \mathrm{~A}$ progenitor cells into oligodendrocytes was not affected by coculture with type 1 astrocytes (Table $4 B$ ). While the number of oligodendrocyte-containing clones was unaffected by coculture of A2B5 + cell-enriched spinal cord cells with type 1 astrocytes, the number of astrocyte-containing clones increased dramatically over that seen on poly-L-lysine-from $15 \%$ on poly-L-lysine to greater than $70 \%$ on an astrocyte monolayer (Table 4). At the same time, the proportion of exclusively A2B5+ precursor cell clones decreased from $50 \%$ on poly-L-lysine to zero on astrocytes. These observations suggest that coculture with type 1 astrocytes in the absence of serum promoted the differentiation of A2B5+ astrocyte precursors into astrocytes. It seems likely that the clonal progeny of $\mathrm{O} 2 \mathrm{~A}$ progenitor cells differentiated into type 2 astrocytes when grown on astrocyte monolayers in the presence of serum. For example, under these conditions no clones containing oligodendrocytes developed, while the proportion of clones containing astrocytes increased over that seen in the absence of serum. The absence of oligodendrocytes and increase in astrocyte-containing clones in the presence of serum is consistent with the switching of bipotential $\mathrm{O} 2 \mathrm{~A}$ progenitor cell differentiation from oligodendrocytes to type 2 astrocytes (Table 4). Taken together, these observations suggest that in the absence of serum, coculture on a type 1 astrocyte monolayer promoted astrocyte differentiation of A2B 5 - astrocyte precursors while $\mathrm{O} 2 \mathrm{~A}$ progenitors differentiated into oligodendrocytes as previously described (Raff et al., 1985; Temple and Raff, 1986). In the presence of serum, as on a poly-L-lysine substrate, both A2B5 + astrocyte precursors and $\mathrm{O} 2 \mathrm{~A}$ progenitors differentiated into astrocytes. 

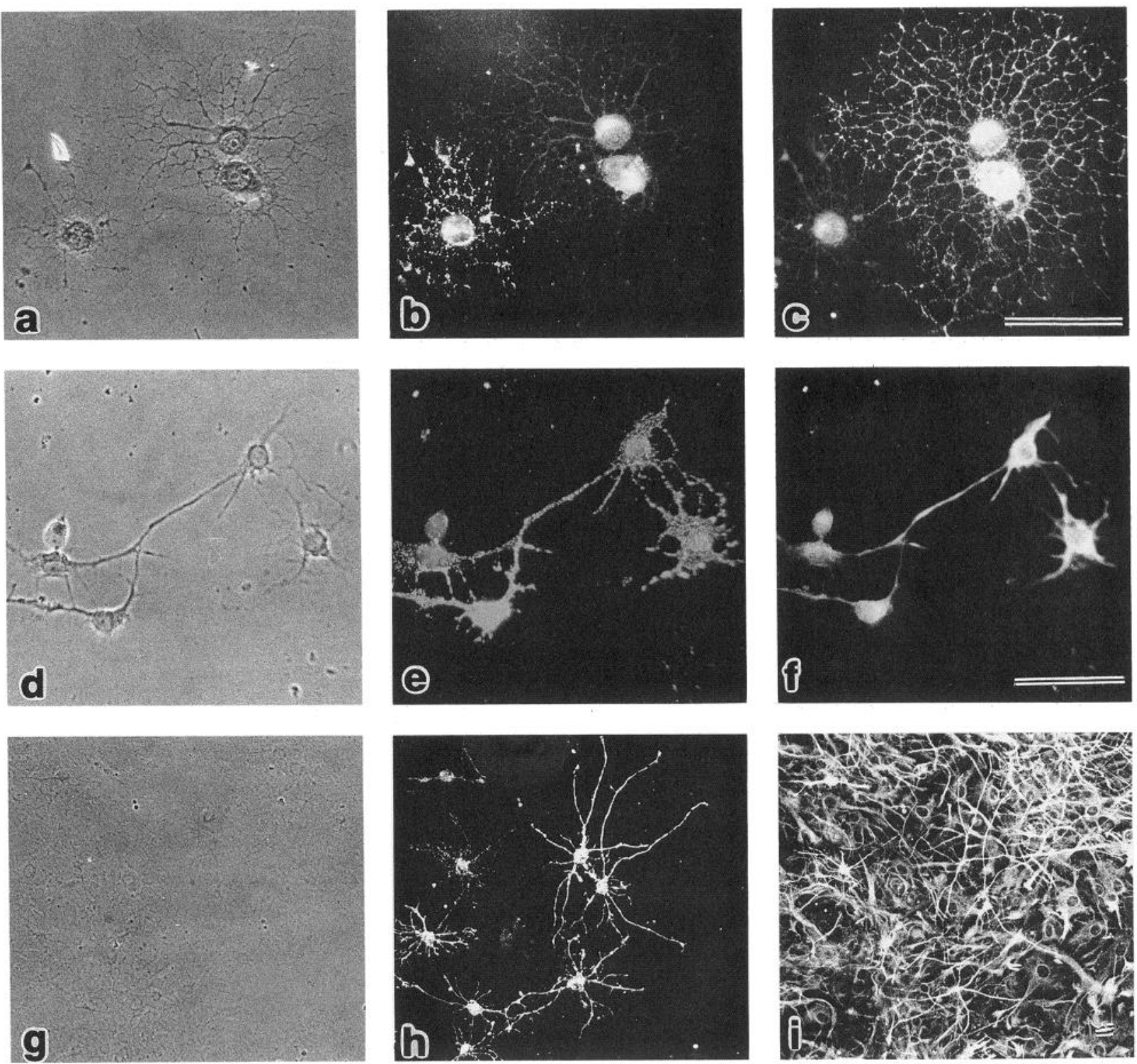

Figure 3. Clonal cultures of A2B5 + cells grown on a poly-L-lysine substrate in the absence of serum ( $a-c)$, on a poly-L-lysine substrate in the presence of serum $(d-f)$, or on a monolayer of type 1 astrocytes in the absence of serum $(g-i) . a, d$, and $g$ are phase-contrast images; $b, e$, and $h$ are labeled with A2B5; $c$ is labeled with anti-GC; and $f$ and $i$ are labeled with anti-GFAP antibodies. In the absence of serum, many of the clones containing oligodendrocytes also contained some A2B5 + cells $(a-c)$. In sister cultures in the presence of serum, the majority of clones contained $\mathrm{A} 2 \mathrm{~B} 5+, \mathrm{GFAP}+$ cells $(d-f)$. In the absence of serum, but on a monolayer of type 1 astrocytes, the majority of clones containing A2B5 + cells were process-bearing astrocytes $(g-i)$. Note that the GFAP staining of the process-bearing A2B $5+$ astrocytes in $i$ is more difficult to detect against the background of type 1 astrocyte staining. Scale bars, $50 \mu \mathrm{m}$.

\section{$A 2 B 5+$ astrocyte precursor cells proliferate in response to serum}

In the clonal analysis of A2B5+ spinal cord glial precursors, not only were astrocyte-containing clones more common in the presence of serum than in its absence, but the number of cells per clone was also significantly larger. For example, after $4 \mathrm{~d}$ in the absence of serum, astrocyte- or oligodendrocyte-containing clones were typically composed of two to three cells and no clones contained more than four cells. However, in the presence of serum, more than $20 \%$ of the astrocyte clones contained at least 4 cells, and the largest clone contained 12 cells, suggesting that serum promotes proliferation of $\mathrm{A} 2 \mathrm{~B} 5+$ astrocyte precur- sors. To examine the effects of factors known to regulate glial cell division, we compared BrdU incorporation in A2B5+ cells from spinal cord and optic nerve in the presence of serum, PDGF and FGF. In the presence of serum, $52 \%$ of spinal cord A2B5+ cells incorporated BrdU (Fig. 4). By contrast, only $17 \%$ of A2B5+ optic nerve cells incorporated BrdU in parallel experiments (Table 5). PDGF and FGF were mitogenic for similar proportions of cells in both spinal cord and optic nerve cultures (Table 5). Furthermore, in spinal cord cultures, the proportion of cells incorporating BrdU in the presence of both serum and PDGF did not increase over that seen with PDGF alone (Table 5 ), suggesting that serum promoted proliferation in only a subpopulation of PDGF-responsive A2B5+ cells. 

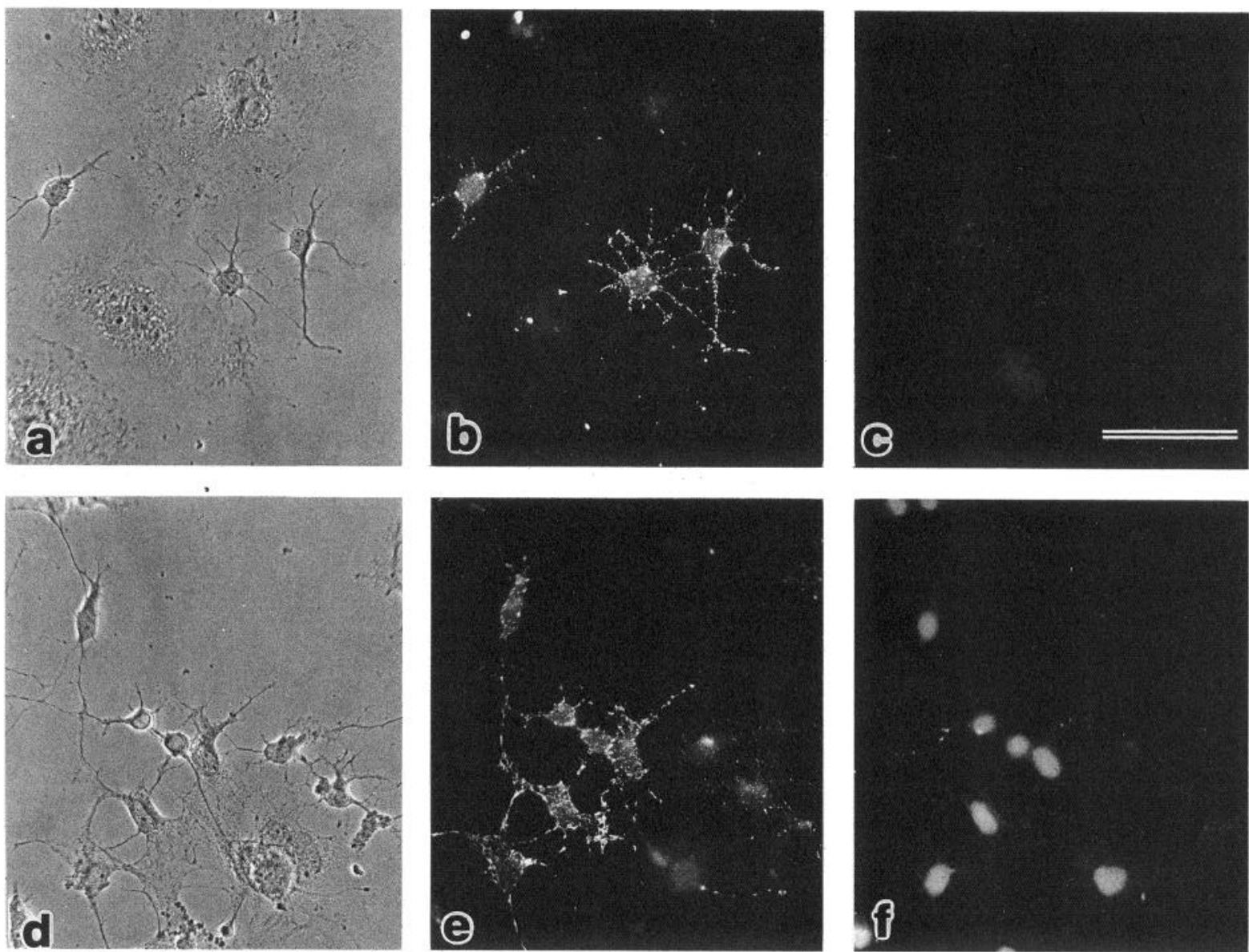

Figure 4. Spinal cord A2B5+ cells proliferate in the presence of serum. Cultures of $\mathrm{P} 0$ rat spinal cord were grown with BrdU either in the absence $(a-c)$ or presence of $10 \%$ FBS $(d-f)$ and labeled with A2B5 $(b, e)$ and anti-BrdU antibodies $(c, f)$. In the absence of serum, few flat cells or processbearing A2B5 + cells proliferated, as shown by the lack of incorporation of BrdU. By contrast, in the presence of $10 \%$ FBS, more than half of the $\mathrm{A} 2 \mathrm{~B} 5+$ cells, as well as some of the fat cells, underwent division during an $18 \mathrm{hr}$ pulse of BrdU. Scale bar, $50 \mu \mathrm{m}$.

Table 5. BrdU incorporation in A2B5+ cell-enriched P0 spinal cord and $\mathbf{P 7}$ optic nerve cells

\begin{tabular}{lcc} 
& \multicolumn{2}{l}{$\begin{array}{l}\text { \% A2B5+ cells } \\
\text { incorporating BrdU }\end{array}$} \\
\cline { 2 - 3 } & $\begin{array}{l}\text { A2B5+ cell- } \\
\text { enriched spinal } \\
\text { cord cultures }\end{array}$ & $\begin{array}{l}\text { Optic nerve } \\
\text { cultures }\end{array}$ \\
\hline Culture condition & $6 \pm 1$ & $2 \pm 3$ \\
Serum free & $52 \pm 2$ & $17 \pm 4$ \\
$10 \%$ FBS & $77 \pm 7$ & $75 \pm 4$ \\
PDGF $(6 \mathrm{ng} / \mathrm{ml})$ & $59 \pm 6$ & $51 \pm 4$ \\
FGF $(2 \mathrm{ng} / \mathrm{ml})$ & $72 \pm 3$ & ND
\end{tabular}

A2B5+ cell-enriched spinal cord or complete optic nerve cells were grown in the absence of serum for $2 \mathrm{~d}$, followed by an additional $2 \mathrm{~d}$ in the presence of serum or growth factors. Cultures were pulsed with BrdU for the last $18 \mathrm{hr}$, and the proportion of proliferating A2B5 + cells was assayed. In the absence of serum, few A2B5 + cells in either culture proliferated. However, in the presence of serum, more than half the spinal cord A2B5 + cells proliferated while only $17 \%$ of optic nerve cells proliferated. Similar proportions of A2B5+ cells in both cultures proliferated in the presence of PDGF and FGF. No increase in the number of proliferating cells was seen in spinal cord cells with the addition of both PDGF and serum over that of PDGF alone, suggesting that only a subpopulation of the PDGF-responsive A2B5+ cells responded to serum. The data represent the mean \pm SD from three experiments in which more than 200 A2B5+ cells were assayed in each experiment. ND, experiment not done.
Two observations indicate that serum acted predominantly as a mitogen for A2B5+ astrocyte precursors and not for $\mathrm{O} 2 \mathrm{~A}$ progenitor cells. First, when A2B5 + spinal cord cells were grown for $3 \mathrm{~d}$ in the absence of serum, allowing differentiation of $\mathrm{O} 2 \mathrm{~A}$ progenitor cells into oligodendrocytes, and subsequently replated and cultured for $3 \mathrm{~d}$ at clonal density in the presence of

Table 6. Proliferation of serum-responsive cells in P7 optic nerve and $\mathbf{P 0}$ spinal cord cultures

$\%$ Total process-bearing cells

\begin{tabular}{llllr}
\cline { 2 - 5 } Culture & BrdU+ & $\begin{array}{l}\text { A2B5+ } \\
\text { BrdU }+\end{array}$ & $\begin{array}{l}\text { GC }+ \\
\text { BrdU }+\end{array}$ & \multicolumn{1}{c}{$\begin{array}{l}\text { GFAP+ } \\
\text { BrdU+ }\end{array}$} \\
\hline P7 optic nerve & $14 \pm 8$ & $10 \pm 2$ & $1 \pm 1$ & $6 \pm 3$ \\
P0 spinal cord & $68 \pm 8$ & $59 \pm 10$ & $3 \pm 1$ & $37 \pm 6$ \\
\hline
\end{tabular}

Spinal cord but not optic nerve cultures contain large numbers of A2B5+ astrocyte precursors that proliferate in response to serum. P0 A2B5 + cell-enriched cultures and P7 optic nerve cultures were grown for $2 \mathrm{~d}$ in the presence of serum and pulsed with BrdU for the last $18 \mathrm{hr}$ to label proliferating cells. Cultures were then switched to serum-free medium in the absence of BrdU to allow cell differentiation to occur. In spinal cord cultures approximately $70 \%$ of process-bearing cells incorporated BrdU, while in optic nerve cultures approximately $15 \%$ of cells incorporated BrdU. In both cultures, less than $3 \%$ of the BrdU-labeled cells subsequently differentiated into GC+ oligodendrocytes, although in spinal cord large numbers of A2B5 + astrocytes were labeled, consistent with the proliferation of A2B5 + astrocyte precursors in the presence of serum. Data represent the mean \pm SD from at least three separate experiments. 

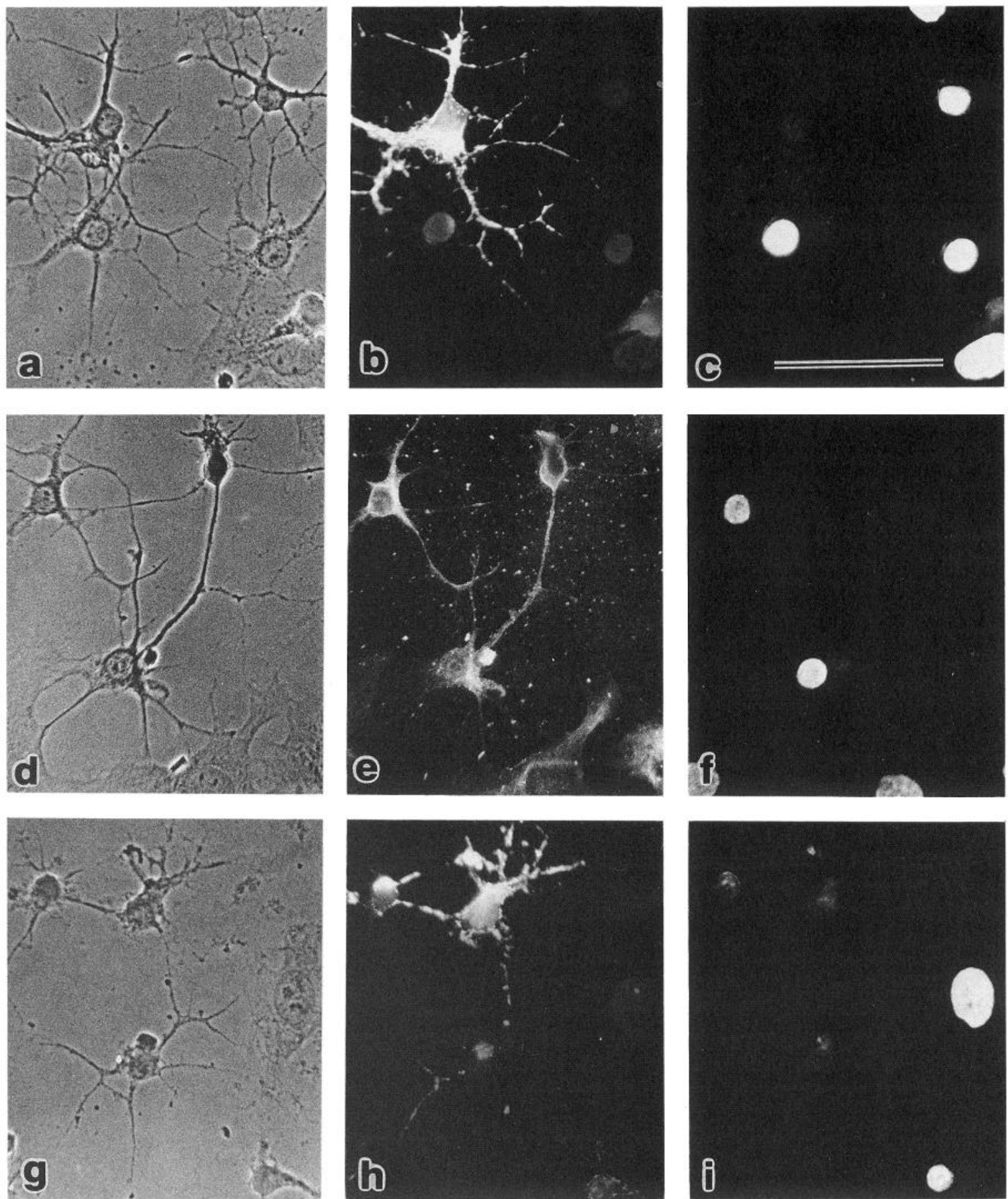

Figure 5. Spinal cord A2B5 + cells that proliferate in the presence of serum subsequently give rise to astrocytes and not oligodendrocytes. Cultures of P0 A2B5 + cell-enriched rat spinal cords $(a-f)$ and P7 optic nerve $(g-i)$ were grown in the presence of $10 \%$ FBS for 2 d, the last $18 \mathrm{hr}$ also in the presence of BrdU, and then switched to serum-free medium to allow cell differentiation to occur. Cultures were double labeled with either antiGC $(b, h)$ or anti-GFAP $(e)$ and anti-BrdU antibodies $(c, f, i)$ as described in Materials and Methods. In spinal cord cultures many process-bearing cells incorporated $\mathrm{BrdU}(c, f)$. These cells did not subsequently differentiate into oligodendrocytes $(b)$ but into GFAP+ astrocytes $(e)$. In optic nerve cultures, fewer process-bearing cells incorporated BrdU, and as in spinal cord, these cells did not subsequently differentiate into GC + oligodendrocytes (h). $a, d$, and $g$ are matching phase-contrast micrographs for each fluorescent panel. $b, e$, and $h$ were visualized under fluorescein optics. $c$, $f$, and $i$ are identical fields visualized under rhodamine optics. Scale bar, $50 \mu \mathrm{m}$.

serum, more than $75 \%$ of the cells that proliferated in the presence of serum gave rise to clones comprised of process-bearing astrocytes and/or A2B5+ cells (data not shown). Since O2A progenitor cells differentiated rapidly into type 2 astrocytes in the presence of serum, the multicellular clones that developed in the presence of serum are most likely derived from A2B5+ astrocyte precursors and not $\mathrm{O} 2 \mathrm{~A}$ progenitors. Second, $\mathrm{P} 0$-derived A2B5+ spinal cord and P7 optic nerve cells were grown for $2 \mathrm{~d}$ in serum and pulsed with $20 \mu \mathrm{M}$ BrdU for the last $18 \mathrm{hr}$ to label actively proliferating cells. The cultures were then 

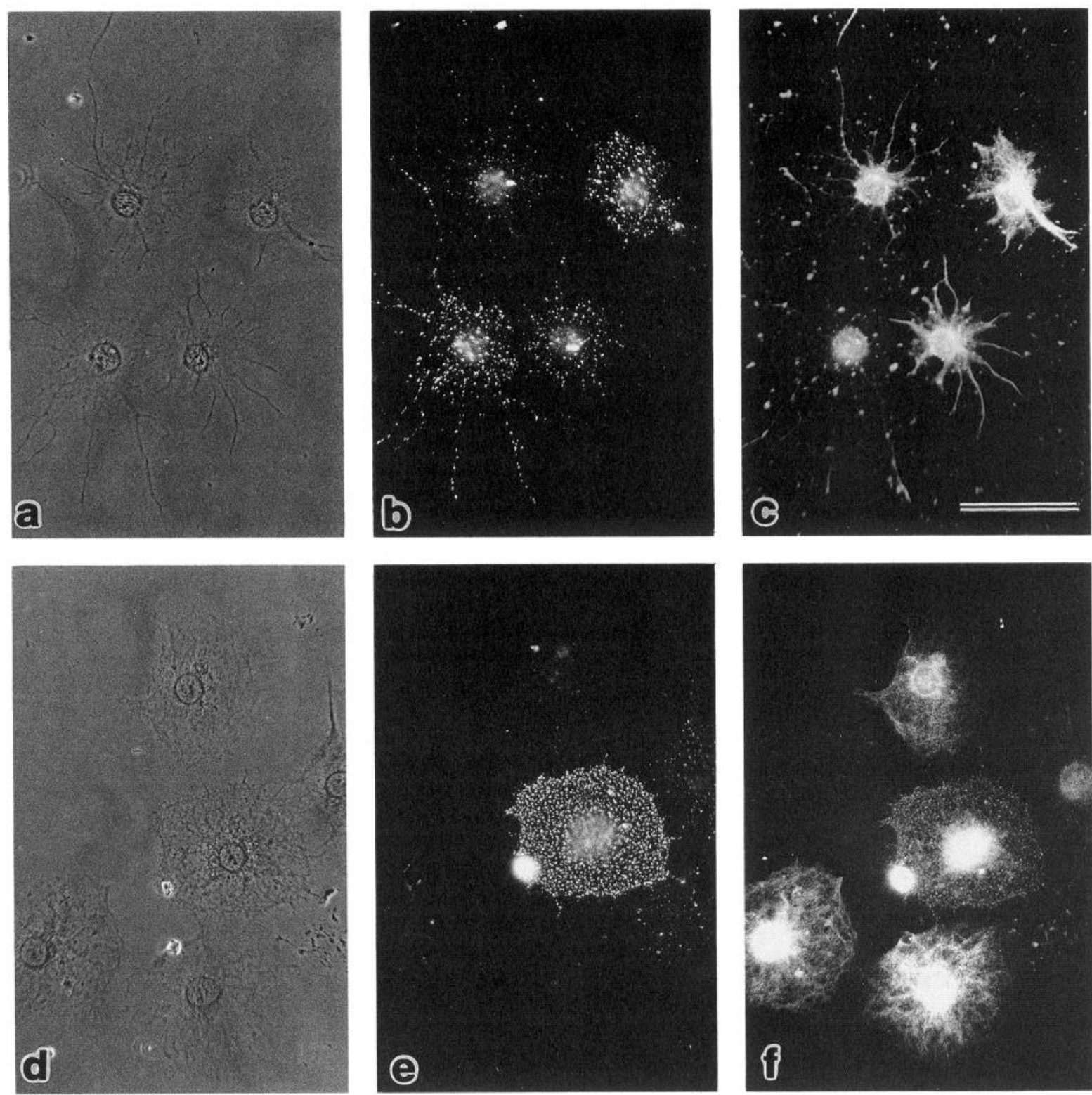

Figure 6. Examples of clonal cultures of A2B5+ astrocyte precursors grown for $10 \mathrm{~d}$ in the presence of serum and labeled with A2B5 $(b, e)$ and anti-GFAP $(c, f)$ antibodies. Two morphologically distinct types of astrocytes developed: A2B5+, GFAP+ process-bearing astrocytes $(a-c)$ and "pancake"-shaped astrocytes $(d-f)$. In general, the morphology of cells within a clone was similar; however, particularly in pancake-shaped clones, not all cells were A2B5 immunoreactive (compare $e$ and $f$ ). Scale bar, $50 \mu \mathrm{m}$.

switched to serum-free medium in the absence of BrdU to allow cell differentiation to occur and the proportion of BrdU-labeled oligodendrocytes and astrocytes determined (Table 6). In spinal cord cultures, approximately $70 \%$ of the process-bearing cells incorporated $\mathrm{BrdU}$ but less than $3 \%$ of these cells subsequently differentiated into oligodendrocytes (Fig. 5). The majority of BrdU-labeled cells were either A2B5+ precursors or GFAP+ process-bearing astrocytes (Table 6, Fig. 5). By comparison, in optic nerve cultures, less than $15 \%$ of process-bearing cells incorporated BrdU and virtually none of these cells differentiated into oligodendrocytes (Table 6, Fig. 5).

These observations demonstrate that the cells stimulated to proliferate by the presence of serum subsequently gave rise to astrocytes but not oligodendrocytes when allowed to differentiate in the absence of serum. Thus, although both O2A progenitor cells and A2B5+ astrocyte precursors proliferate in re- sponse to PDGF, only the A2B5+ astrocyte precursors appear to proliferate in response to serum.

\section{A2B5+ astrocyte precursors give rise to morphologically distinct classes of astrocytes}

To determine the morphological and antigenic phenotype of the progeny of the A2B5+ astrocyte precursor population, single cells from A2B5 + cell-enriched spinal cord cultures that proliferated in the presence of serum were allowed to develop into clones for up to $10 \mathrm{~d}$. When cultured on poly-L-lysine substrate, cells in astrocyte-containing clones were of two distinct morphologies: process-bearing or a distinctive "pancake"-shaped morphology (Fig. 6). Within a single clone, although the morphology of individual cells was generally similar, not every cell labeled with A2B5 (Fig. 6), indicating that A2B5 immunoreactivity does not define all stages of differentiation in A2B5+ 
astrocyte precursor development. In general, the majority of process-bearing cells retained A2B5 immunoreactivity while many pancake-shaped cells lacked A2B5 immunoreactivity. By observing single clones on a daily basis, it appeared that clones of pancake-shaped astrocytes arose from process-bearing cells that proliferated and that subsequently assumed the pancake morphology. This morphological conversion was not, however, necessarily coincident with a loss of A2B5 immunoreactivity.

When $\mathrm{A} 2 \mathrm{~B} 5+$ astrocyte precursor cells were grown on type 1 astrocytes, the morphology of the astrocyte progeny was dramatically different from that seen on a poly-L-lysine substrate. On type 1 astrocytes, A2B5+ astrocytes derived from A2B5+ astrocyte precursors were invariably process bearing (Fig. $3 h$ ) and their processes were often quite long and slender. Clones containing the pancake-shaped A2B5 + astrocytes were seldom seen on type 1 astrocyte monolayers, but were occasionally found occupying holes within the monolayer. Since pancake-shaped astrocytes lose A2B5 immunoreactivity, their detection against a background of type 1 astrocytes is difficult. It may be, however, that contact between type 1 astrocytes and the progeny of the $\mathrm{A} 2 \mathrm{~B} 5+$ astrocyte precursor cells is required to maintain the process-bearing morphology.

These studies suggest that at least three distinct glial precursor cells were present in cultures of neonatal rat spinal cord: (1) A2B5 - cells that give rise to flat type 1-like astrocytes and that do not migrate extensively from explants; (2) A2B5+, migratory $\mathrm{O} 2 \mathrm{~A}$-like progenitor cells that give rise to oligodendrocytes or type 2 astrocytes and proliferate in response to PDGF but not serum; and (3) A2B5+, migratory astrocyte precursor cells that proliferate in response to both PDGF and serum. On a polyL-lysine substrate, the A2B5 + astrocyte precursors differentiated initially into process-bearing and subsequently into pancake-shaped astrocytes in the presence of serum. In coculture with type 1 astrocytes, A2B5 + astrocyte precursors rapidly differentiated into process-bearing astrocytes in the absence of serum.

\section{Discussion}

We have examined glial development in cultures of newborn rat spinal cord and show that unlike optic nerve cultures, the $\mathrm{A} 2 \mathrm{~B} 5+$ migratory process-bearing population in spinal cord cultures contain two distinct populations of glial precursor cells. Some of these A2B5+ glial precursors resemble optic nerve O2A progenitor cells (Raff, 1989); they proliferate in response to PDGF (Noble et al., 1988) and FGF (Bogler et al., 1990; McKinnon et al., 1990) and in the absence of serum differentiate into oligodendrocytes; while in the presence of serum they may differcntiatc into $\mathrm{A} 2 \mathrm{~B} 5+$ process-bearing type 2-like astrocytes. The majority of $\mathrm{A} 2 \mathrm{~B} 5+$ glial precursors in newborn rat spinal cord cultures, however, are astrocyte precursors, and such cells appear to be absent or rare in optic nerve cultures.

Spinal cord A2B5+ astrocyte precursors share a number of characteristics with $\mathrm{O} 2 \mathrm{~A}$ progenitor cells. They have a processbearing morphology and strong A2B5 immunoreactivity. These cells actively migrate from newborn spinal cord explants and proliferate in response to PDGF and FGF. However, unlike $\mathrm{O} 2 \mathrm{~A}$ progenitor cells, A2B5+ astrocyte precursors do not give rise to oligodendrocytes. When grown under conditions that result in the differentiation of $\mathrm{O} 2 \mathrm{~A}$ progenitors into oligodendrocytes, most A2B5 + astrocyte precursors retain a precursorlike phenotype. Furthermore, although these cells differentiate into astrocytes in the presence of serum (as do O2A progenitor cells), they are also stimulated to proliferate by serum.

Spinal cord A2B5 + astrocyte precursors also share some similarities with optic nerve type 1 astrocyte precursors. Both cell types proliferate in response to serum, and both appear to give rise only to astrocytes. These two astrocyte precursors, however, differ in a number of important ways. Optic nerve type 1 astrocyte precursors lack A2B5 immunoreactivity and a processbearing morphology (Raffet al., 1984) and are not highly motile, while the spinal cord A2B5 I astrocytc precursor cclls are $\mathrm{A} 2 \mathrm{~B} 5+$, process bearing, and more migratory than type 1 astrocyte precursors. Furthermore, type 1 astrocyte precursors give rise to flat astrocytes with a fibroblast-like morphology in both optic nerve (Raff et al., 1983b, 1984) and spinal cord cultures, while A2B5+ astrocyte precursors give rise to either processbearing or specific "pancake"-shaped astrocytes. Single cell cloning studies have shown that these pancake-shaped cells represent a different class of astrocytes from type 1-like astrocytes in spinal cord cultures (Miller and Szigeti, 1991).

The relationship of the A2B5 + astrocyte precursors to other glial precursors in rat spinal cord cultures is unclear. One possibility is that they represent $\mathrm{O} 2 \mathrm{~A}$ progenitor cells at a stage of development after commitment to the type 2 astrocyte differentiation pathway but before GFAP expression. The differences in response of $\mathrm{O} 2 \mathrm{~A}$ progenitors and $\mathrm{A} 2 \mathrm{~B} 5+$ astrocyte precursors to mitogenic and differentiation signals, however, make this unlikely.

It may be that the A2B5+ astrocyte precursors represent type 1 astrocyte precursors at an early stage of development, since type 1 astrocytes are thought to be derived from radial glial cells, and A2B5 + radial glia have been described in the spinal cord (Frederiksen and McKay, 1988). In other systems, however, no A2B5 + cells have been described in the type 1 astrocyte lineage, while in P0 spinal cord cultures, A2B5 antibody-mediated complement cell lysis did not significantly reduce the number of flat type 1-like astrocytes that subsequently developed. Furthermore, in long-term clonal cultures, A2B5+ astrocyte precursors gave rise to clones of either process-bearing astrocytes or specific pancake-shaped astrocytes, neither of which underwent further morphological transformation to fibroblastic type 1-like astrocytes.

The most likely possibility is that A2B 5 । astrocytc precursors represent a discrete astrocyte precursor that gives rise to a distinct class of astrocytes. Consistent with this hypothesis is the observation that proliferation of these precursor cells is regulated by factors different from those involved in the proliferation of both type 1 astrocyte precursors and $\mathrm{O} 2 \mathrm{~A}$ progenitor cells. For example, A2B5+ astrocyte precursors proliferated in response to both serum and PDGF, while type 1 astrocyte precursors proliferated in response to serum and O2A progenitors proliferated in response to PDGF (Noble et al., 1988). Furthermore, the regulation of differentiation of these precursors into astrocytes is different from that of $\mathrm{O} 2 \mathrm{~A}$ progenitor cells. On a monolayer of type 1 astrocytes in the absence of serum, O2A progenitors differentiated into oligodendrocytes (Raff et al., 1985; Temple and Raff, 1986), while under identical conditions A2B5+ astrocyte precursors differentiated into astrocytes.

$\mathrm{A} 2 \mathrm{~B} 5+$ astrocyte precursors may not be confined to the spinal cord. For example, a small proportion of A2B5+ cells in optic nerve cultures (17\%) undergo DNA synthesis in the presence of serum, while similar glial precursor cells that differentiate into 
astrocytes but not oligodendrocytes have becn demonstrated in cultures of postnatal cerebellum (Levine and Stallcup, 1987; Levine, 1989) or P30 rat forebrain (Norton and Farooq, 1989).

Neither the initial origin nor the location of the differentiated progeny of the A2B5+ astrocyte precursors has been defined in the intact spinal cord. One possibility is that these cells represent the progeny of radial glial cells. In other regions of the CNS, radial glia appear to differentiate into astrocytes (Choi and Lapham, 1978; Schmechel and Rakic, 1979; Levitt and Rakic, 1980; Choi et al., 1983). Consistent with this hypothesis are preliminary studies suggesting that in early development, A2B5+ astrocyte precursors are restricted to ventral regions of the spinal cord (J. Fok-Seang and R. H. Miller, unpublished observations), while A2B5-immunoreactive radial glial cells have also been shown to be restricted to ventral regions of the embryonic spinal cord (Frederiksen and McKay, 1988). Alternatively, A2B5+ astrocyte precursors may be derived from cells around the central canal in the ventral spinal cord. Recent studies suggest that this region also gives rise to oligodendrocytes in the developing spinal cord (Warf et al., 1991; E. Noll and R. H. Miller, unpublished observations).

The spinal cord is a comparatively complex region of the CNS, containing multiple different axon tracts as well as central gray matter. Although the functions of astrocytes are still unclear, they have been proposed to support axonal growth (Silver et al., 1982) and the migration of neuronal precursors (Rakic, 1971; Hatten, 1990) to their correct destination during CNS development. In the adult CNS, astrocytes appear to assist in the formation of the blood-brain barrier (Janzer and Raff, 1987), form glial scars following injury (Maxwell and Kruger, 1965; Nathaniel and Nathaniel, 1981), maintain the ionic environment (Hertz, 1981), and isolate neuronal elements (Peters et al., 1976). If specific classes of astrocytes have a restricted repertoirc of functions, then since spinal cord contains multiple axon tracts and distinct neuronal populations, it may be that multiple classes of astrocytes, derived from distinct precursors, are required to perform discrete functions in the developing and adult spinal cord.

\section{References}

Abney ER, Bartlett PP, Raff MC (1981) Astrocytes, ependymal cells and oligodendrocytes develop on schedule in dissociated cell cultures of embryonic rat brain. Dev Biol 83:301-310.

Barbin G, Manthorpe M, Varon S (1984) Purification of the chick ciliary ncuronotrophic factor. J Neurochem 43:1468-1478.

Bartlett PP, Noble MD, Pruss RM, Raff MC, Rattray S, Williams CA (1981) Rat neural antigen-2 (Ran-2): a cell surface antigen on astrocytes, ependymal cells, Muller cells and leptomeninges defined by a monoclonal antibody. Brain Res 204:339-351.

Behar T, McMorris FA, Novotny EA, Barker JL, Dubois-Dalcq M (1988) Growth and differentiation properties of O-2A progenitors purified from rat cerebral hemispheres. J Neurosci Res 21:168-180.

Bignami A, Dahl D (1974) Astrocyte-specific protein and radial glia in the cerebral cortex of new-born rat. Nature 252:55-56.

Bignami A, Eng LF, Dahl D, Uyeda CT (1972) Localization of the glial fibrillary acidic protein in astrocytes by immunofluorescence. Brain Res 43:429-435.

Bogler O, Wren D, Barnett SC, Land H, Noble M (1990) Co-operation between two growth factors promotes extended self-renewal and inhibits differentiation of the oligodendrocyte-type- 2 astrocyte $(\mathrm{O}-2 \mathrm{~A})$ progenitor cells. Proc Natl Acad Sci USA 87:6368-6372.

Bottenstein JE, Sato GH (1979) Growth of a rat neuroblastoma cell line in serum-free supplemented medium. Proc Natl Acad Sci USA 76:514-517.

Bunge RP (1968) Glial cells and the central myelin sheath. Physiol Rev 48:197-251.
Choi BH, Lapham LW (1978) Radial glia in the fetal ccrcbrum: a combined Golgi, immunofluorescent and electron microscopic study. Brain Res 148:295-311.

Choi BH, Kim RC, Lapham LW (1983) Do radial glia give rise to both astroglial and oligodendroglial cells? Dev Brain Res 8:119-130.

Culican SM, Baumrind NL, Yamamoto M, Pearlman AL (1990) Cortical radial glia: identification in tissue culture and evidence for their transformation to astrocytes. J Neurosci 10:684-692.

Edwards MA, Yamamoto M, Caviness VS Jr (1990) Organization of radial glia and related cells in the developing murine CNS. An analysis based upon a new monoclonal antibody marker. Neuroscience 36: 121-144.

Eisenbarth GS, Walsh FS, Nirenberg M (1979) Monoclonal antibody to a plasma membrane antigen of neurons. Proc Natl Acad Sci USA 76:4913-4917.

Federoff S, Doering LC (1980) Colony cultures of neural cells as a model for study of cell lineages in the developing CNS: the astrocyte cell lineage. Curr Top Dev Biol 16:283-304.

Federoff S, Neal J, Opas M, Kalnins VI (1984) Astrocyte cell lineage. III. The morphology of differentiating mouse astrocytes in colony cultures. J Neurocytol 13:1-20.

Frederiksen K, McKay RGD (1988) Proliferation and differentiation of rat neuroepithelial precursor cells in vivo. J Neurosci 8:1144-1151.

Fujita S (1965) An autoradiographic study on the origin and fate of the subpial glioblast in the embryonic chick spinal cord. J Comp Neurol 124:51-60.

Gilmore SA (1971) Neuroglial population in the spinal white matter of neonatal and early post-natal rats: an autoradiographic study of numbers of neuroglia and changes in their proliferative activity. Anat Rec 171:283-292.

Hatten ME (1990) Riding the glial monorail: a common mechanism for glial guided neuronal migration in different regions of the developing brain. Trends Neurosci 13:179-184.

Hertz L (1981) Functional interactions between astrocytes and neurons. In: Glial and neuronal cell biology (Federoff S, ed), pp 45-58. New York: Liss.

Hirano M, Goldman JE (1988) Gliogenesis in rat spinal cord: evidence for origin of astrocytes and oligodendrocytes from radial precursors. J Neurosci Res 21:155-167.

Hughes SM, Lillien LE, Raff MC, Rohrer H, Sendtner M (1988) Ciliary neurotrophic factor induces type-2 astrocyte differentiation in culture. Nature 335:70-73.

Ingraham CA, McCarthy KD (1989) Plasticity of process-bearing glial cell cultures from neonatal cerebral cortical tissue. J Neurosci 9:6369.

Janzer RC, Raff MC (1987) Astrocytes induce blood brain barrier properties in endothelial cells. Nature 325:253-257.

Juurlink BHJ, FederoffS, Hall C, Nathaniel EJH (1981) Astrocyte cell lineage. I. Astrocyte progenitor cells in mouse neopallium. J Comp Neurol 200:375-391.

I evi G, Gallo V, Wilkin GP, Cohen J (1986a) Astrocyte subpopulations and glial precursors in rat cerebellar cell cultures. Adv Biosci 61:21-30.

Levi G, Gallo V, Ciotti MT (1986b) Bipotential precursors of putative fibrous astrocytes and oligodendrocytes in rat cerebellar cultures express distinct surface features and "neuron-like" gamma-aminobutyric acid transport. Proc Natl Acad Sci USA 83:1504-1 508.

Levi G, Aloisi F, Wilkin GP (1987) Differentiation of cerebellar bipotential glial precursors into oligodendrocytes in primary culture: developmental profile of surface antigens and mitotic activity. J Neurosci Res 18:407-417.

Levine JM (1989) Neuronal influences on glial progenitor cell development. Neuron 3:103-113.

Levine JM, Stallcup WB (1987) Plasticity of developing cerebellar cells in vitro studied with antibodies against the NG2 antigen. J Neurosci 7:2721-2731.

Levitt P, Rakic P (1980) Immunoperoxidase localization of glial fibrillary acidic protcin in radial glial cells and astrocytes of the developing rhesus monkey brain. J Comp Neurol 193:815-840.

Lillien LE, Sendtner M, Raff MC (1990) Extracellular matrix-associated molecules collaborate with ciliary neurotrophic factor to induce type-2 astrocyte development. J Cell Biol 111:635-644.

Ling EA (1976) Study in the changes of the proportions and numbers of the various glial cell types in the spinal cord of neonatal and young adult rats. Acta Anat 96:188-195. 
Maxwell DS, Kruger L (1965) The fine structure of astrocytes in the cerebral cortex and their response to focal injury produced by heavy ionizing particles. J Cell Biol 25:141-157.

McKinnon RD, Matsui T, Dubois-Dalcq M, Aaronson SA (1990) FGF modulates the PDGF-driven pathway of oligodendrocyte development. Neuron 5:603-614.

Miller RH, Szigeti V (1991) Clonal analysis of astrocyte diversity in neonatal rat spinal cord cultures. Development 113:353-362.

Miller RH, David S, Patel R, Abney ER, Raff MC (1985) A quantitative immunohistochemical study of macroglial cell development in the rat optic nerve: in vivo evidence for two distinct glial cell lineages. Dev Biol 111:35-41.

Miller RH, ffrench-Constant C, Raff MC (1989) The macroglial cells of the rat optic nerve. Annu Rev Neurosci 12:517-534.

Nathaniel EJH, Nathaniel DR (1981) The reactive astrocyte. In: Advances in cellular neurobiology, Vol 2 (Federoff S, Hertz L, eds), pp 249-301. New York: Academic.

Noble M, Murray K, Siroobant P, Waterfeld MD, Riddle P (1988) Platelet-derived growth factor promotes division and motility and inhibits premature differentiation of the oligodendrocyte/type- 2 astrocyte progenitor cell. Nature 333:560-562.

Norton WT, Farooq M (1989) Astrocytes cultured from mature brain derive from glial precursor cells. J Neurosci 9:769-775.

Nowakowski RS, Lewin SB, Miller MW (1989) Bromodeoxyuridine immunohistochemical determination of the lengths of the cell cycle and the DNA-synthetic phase for an anatomically defined population. J Neurocytol 18:311-318.

Peters A, Palay SL, de F Webster H (1976) The fine structure of the nervous system: the neurons and the supporting cells. Philadelphia: Saunders.

Raff MC (1989) Glial cell diversification in the rat optic nerve. Science 243:1450-1455.

Raff MC, Mirsky R, Fields KL, Lisak RP, Dorfman SH, Silberberg DH, Gregson NA, Liebowitz S, Kennedy MC (1978) Galactocerebroside is a specific cell surface antigenic marker for oligodendrocytes in culture. Nature 274:813-816.

Raff MC, Miller RH, Noble M (1983a) A glial progenitor cell that develops in vitro into an astrocyte or an oligodendrocyte depending on the culture medium. Nature 303:390-396.

Raff MC, Abney ER, Cohen J, Lindsay R, Noble M (1983b) Two types of astrocytes in cultures of developing rat white matter: differences in morphology, surface gangliosides, and growth characteristics. J Ncurosci 3:1289-1300.

Raff MC, Abney ER, Miller RH (1984) Two glial cell lineages diverge prenatally in the rat optic nerve. Dev Biol 106:53-60.

Raff MC, Abney ER, Fok-Seang J (1985) Reconstitution of a developmental clock in vitro: a critical role for astrocytes in the timing of oligodendrocyte differentiation. Cell 42:61-69.

Rakic P (1971) Neuron-glial relationship during granule cell migration in developing cerebellar cortex. A Golgi and electron microscopic study in Macacus rhesus. J Comp Neurol 141:238-312.

Ranscht B, Clapshaw PA, Price J, Noble M, Seifert W (1982) Development of oligodendrocytes and Schwann cells studied with a monoclonal antibody against galactocerebroside. Proc Natl Acad Sci USA 79:2709-2713.

Richardson WD, Pringle N, Mosley MJ, Westermark B, Dubois-Dalcq
$M$ (1988) A role for platelet-derived growth factor in normal gliogenesis in the central nervous system. Cell 53:309-319.

Sasahara M, Fries JWU, Raines EW, Gown AM, Westrum LE, Frosch MP, Bonthron DT, Ross R, Collins T (1991) PDGF B-chain in neurons of the central nervous system, posterior pituitary and in a transgeneic model. Cell 64:219-227.

Schachner M (1982) Immunological analysis of cellular heterogeneity in the cerebellum. In: Neuroimmunology (Brockes J, ed), pp 215250. New York: Plenum.

Schachner M, Hedley-Whyte ET, Hsu DW, Schoonmaker G, Bignami A (1977) Ultrastructural localization of glial fibrillary acidic protein in mouse cerebellum by immunoperoxidase labelling. J Cell Biol 75: 67-73.

Schachner M, Kim SK, Zehnle R (1981) Developmental expression in central and peripheral nervous system of oligodendrocytc cell surface antigens ( $O$ antigens) recognized by monoclonal antibodies. Dev Biol 83:328-338.

Schmechel DE, Rakic P (1979) A Golgi study of radial glial cells in developing monkey telencephalon: morphogenesis and transformation into astrocyte. Anat Embryol 156:115-152.

Silver J, Lorenz SE, Wahlsten D, Coughlin J (1982) Axonal guidance during the development of the great cerebral commissures: descriptive and experimental studies in vivo on the role of preformed glial pathways. J Comp Neurol 210:10-29.

Skoff RP, Price D, Stocks A (1976a) Electron microscopic autoradiographic studies of gliogenesis in rat optic nerve. I. Cell proliferation. J Comp Neurol 169:291-312.

Skoff RP, Price D, Stocks A (1976b) Electron microscopic autoradiographic studies of gliogenesis in rat optic nerve. II. Time of origin. J Comp Neurol 169:313-333.

Small RK, Riddle P, Noble M (1987) Evidence for migration of oligodendrocyte-type-2 astrocyte progenitor cells into the developing rat optic nerve. Nature 328:155-157.

Smith GM, Rutishauser U, Silver J, Miller RH (1990) Maturation of astrocytes in vitro alters the extent and molecular basis of neurite outgrowth. Dev Biol 138:377-390.

Sommer I, Schachner M (1981) Monoclonal antibodies (O1-O4) for oligodendrocyte cell surfaces: an immunocytochemical study in the central nervous system. Dev Biol 83:311-327.

Sturrock RR (1982) Gliogenesis in the prenatal rabbit spinal cord. J Anat 134:771-793.

Temple S, Raff MC (1985) Differentiation of a bipotential glial progenitor cell in single cell microculture. Nature 313:223-225.

Temple S, Raff MC (1986) Clonal analysis of oligodendrocyte development in culture: evidence for a developmental clock that counts cell divisions. Cell 44:773-779.

Warf BC, Fok-Seang J, Miller RH (1991) Evidence for the ventral origin of oligodendrocytes in the rat spinal cord. J Neurosci 11:24772488.

Yeh HJ, Ruit KG, Wang Y, Parks WC, Snider WD, Deuel TF (1991) PDGF-A chain gene is expressed by mammalian neurons during development and in maturity. Cell 64:209-216.

Yong VW, Kim SU (1987) A new double labeling immunofluorescence technique for the determination of proliferation of human astrocytes in culture. J Neurosci Methods 21:9-16. 